\title{
NARRATIVA URUGUAYA CONTEMPORÁNEA: PERIODIZACIÓN Y CAMBIO LITERARIO
}

\author{
POR \\ HUGO J. VERANI \\ University of California, Davis
}

Todo planteamiento de la evolución de la literatura en una época y un ámbito determinados exige esclarecer previamente los principios teóricos adoptados para articular históricamente la sucesión de obras y de autores particulares. La justificación del criterio de periodización es uno de los quehaceres más problemáticos de la historia literaria. La tarea fundamental consiste en desarrollar una indagación sistemática del devenir de la literatura como signo estético sin simplificar la compleja interacción recíproca entre literatura y factores concomitantes - tradición cultural en que se inscribe la obra, contexto histórico y social, expectativas del lector-que gravitan sobre cada individuo y afectan el cambio literario. Es necesario distinguir, ante todo, entre la constatación de cambios literarios y su posible explicación histórica. Oldrich Belicafirma que la periodización debe poseer una cualidad absolutamente indispensable, "debe fijar los períodos y descubrir los cambios entre los períodos con la ayuda de criterios única y exclusivamente literarios". ${ }^{1}$ Este criterio basta para describir la evolución literaria, continúa Belic, pero es insuficiente para descubrir sus fuerzas motrices, factores extraliterarios que deben ser considerados, teniendo presente que la literatura nunca es un simple receptor de estímulos: "la literatura es una fuerza activa en la vida de la sociedad humana y hay que estudiarla como tal". ${ }^{2}$ De hecho existe constante interacción entre la literatura y otras actividades humanas, pero la literatura no está subordinada a circunstancias sociales o políticas. El cambio literario no está necesariamente condicionado por sucesos históricos (un reinado, una revolución, una dictadura, etc.), frecuente arbitrariedad que reduce el decurso literario a mero reflejo pasivo de la vida social. La dificultad estriba, precisamente, en integrar estos dos planos dialécticamente relacionados y determinar hasta qué punto la evolución interna de la literatura es modificada por fuerzas sociales.

1 Oldrich Belic, "La periodización y sus problemas", Problemas de Literatura (Santiago de Chile), v. 1, no. 2 (sept. 1972), 18.

${ }^{2}$ Belic, 9. 
A fin de precisar las etapas del cambio literario es imprescindible, a mi juicio, delimitar dos conceptos fácilmente tergiversados: las nociones de perfodo literario y de generación histórica. René Wellek considera el periodo literario como "una sección de tiempo dominada por un sistema de normas literarias cuya introducción, difusión, diversificación, integración y desaparición pueden señalarse". ${ }^{3}$ Con anterioridad los formalistas rusos -Tinianov y Jakobsonhabian destruido la ilusión de homogeneidad, "definir un período de la literatura como realización simple de un solo movimiento".4 El período literario se define por el predominio de una tendencia artística, no por la vigencia exclusiva de determinadas normas, pautas o convenciones. ${ }^{5}$ Es decir, en todo períodocoexisten corrientes literarias heterogéneas - dominantes o subordinadas- que dan densidad y diversidad al fenómeno literario. El predominio de ciertos cánones estéticos e ideológicos determina el carácter distintivo de cada período.

El concepto de período literario se interpenetra con el de generación histórica, unidad cultural primaria para entender el devenir histórico. La noción de generación histórica requiere ciertos deslindes que rectifiquen malentendidos o desconfianzas a priori que enturbien los resultados propuestos. La metodología generacional se presta a equívocos y a distorsiones, debido al determinismo biográfico, la improvisación, la vaguedad de terminologia y la arbitrariedad de criterios taxonómicos. Un síntoma de ello es la heterogeneidad de propuestas existentes, que sorprenden por su falta de fundamentos. ${ }^{6}$ Las

\footnotetext{
${ }^{3}$ René Wellek, "Periods and Movements in Literary History", English Institute Annual 1940 (New York: Columbia University Press, 1941), 89.

${ }^{4}$ Carlos Altamirano y Beatriz Sarlo, Literatura/Sociedad (Buenos Aires: Hachette, 1983), 122.

5 Vítor Manuel de Aguiar e Silva, "La periodización literaria", Teoría de la literatura (Madrid: Gredos, 1972), 248-249.

${ }^{6}$ Prescindo del recuento de los numerosos tratados sobre el tema. S6́lo consigno aquí los aportes que, a mi juicio, son más esclarecedores. Son indispensables los ensayos de Ortega y Gasset, El tema de nuestro tiempo (Madrid: Espasa-Calpe, 1964), 11-18, y En torno a Galileo (Madrid: Revista de Occidente, 1967), 37-98; y el libro de Julián Marías, El método historico de las generaciones, $4^{\mathrm{n}}$ ed. (Madrid: Revista de Occidente, 1967). Además de los trabajos ya mencionados de Belic, Wellek y Aguiar e Silva, sobresalen tres estudios de Claudio Guillén, "Second Thoughts on Literary Periods", Literature as System (Princeton: Princeton University Press, 1971), 420-469; “Cambio literario y múltiple duración”, en Homenaje a Julio Caro Baroja (Madrid: Centro de Investigaciones Sociológicas, 1978), 533-549; y "Las configuraciones históricas: historiología", Entre lo uno y lo diverso (Barcelona: Crítica, 1985), 362-431. Véanse también, "Problèmes de Périodisation dans l'histoire Littéraire", Romanistica Pragensia 4 (Praga), (1968): 5-105; y Neohelicon 12 (Budapest): 1-2 (1972): 177-325, dedicado a corrientes y épocas literarias. En cuanto a su aplicación a la literatura hispanoamericana, el enfoque generacional más sistemático es el de Cedomil Goiç, Historia de la novela hispanoamericana (Valparaíso: Ediciones Universitarias, 1972), y "La Périodisation dans l'histoire de la littérature hispanoaméricaine", Etudes Littéraires 2-3 (1975): 269-284. Goiç estudia la evolución literaria como un fenómeno autónomo, excluyendo toda consideración social.
} 
insuficiencias observadas en la teoría generacional provienen, en gran parte, de la concepción idealista y ahistórica de aplicaciones que desechan la tradición cultural y las relaciones de índole social. Las deficiencias proceden, además, del método de Julius Petersen, de amplia difusión en el mundo hispánico desde 1946, que reduce el concepto de generación a las afinidades entre un grupo de individuos en torno de ocho factores que determinarían la existencia de una generación, criterio insatisfactorio por imponer a cada grupo atributos heterogéneos que rara vez se dan juntos. Pretender fundar una escala generacional como categoría literaria es una propuesta arbitraria, por acentuar la homogeneidad cultural y no admitir la pluralidad, la convivencia de normas disonantes y conflictivas en cualquier período histórico. ${ }^{7}$

Con demasiada frecuencia se tiende a restringir la idea de generación corolario de Petersen- a los postulados de un movimiento o tendencia; el predominio de cierta sensibilidad no excluye la presencia de preferencias radicalmente opuestas en el mismo periodo. Ninguna generación es homogénea: las diferencias entre grupos, promociones o escuelas subrayan la multiplicidad de valores y de formas que se entrecruzan en libertad o en contraposición y se afectan mutuamente. ${ }^{8}$ La coexistencia de todos los contemporáneos en diferentes fases de formación, la convivencia de tendencias antagónicas dentro de la misma generación histórica, la dilatada evolución de ciertos escritores o la tardía aparición de otros, condicionados todos por fuerzas sociales, van enmarañando el tránsito de un periodo al siguiente.

A pesar del descrédito en que ha caído, la doctrina generacional resulta provechosa - como primer paso - para indagar en la actividad cultural de una comunidad, particularmente en períodos de corta duración..$^{9}$ La periodización del devenir de la literatura mediante cortes históricos de lapsos aproximados se fundamenta en unos pocos postulados de probada viabilidad en una sociedad

7 Julius Petersen, "Las generaciones literarias", en Filosofia de la ciencia literaria, ed. Emil Ermatinger (México: Fondo de Cultura Económica, 1946), 137-193.

${ }^{8}$ Claudio Guillén, Entre lo uno y lo diverso, 366-370.

${ }^{9}$ La sociocrítica actual rechaza el esquema generacional y propone seguir criterios interdisciplinarios. Hasta la fecha, los planteamientos se limitan a enu merar principios teóricos e hipótesis de trabajo. Se destacan los estudios de Ángel Rama, "Sistema literario y sistema social en Hispanoamérica", Literaturay praxis en América Latina (Caracas: Monte Ávila, 1974), 81-107; Nelson Osorio, "La nueva narrativa y los problemas de la crítica en Hispanoamérica actual", Revista de critica literaria latinoamericana 5 (Lima, 1977): 7 26; Antonio Cornejo Polar, "Unidad, pluralidad, totalidad: el corpus de la literatura latinoamericana", Sobreliteratura y crtticalatinoamericana (Caracas: Universidad Central de Venezuela, 1982), 33-50; Luis Lopez Oliver, "Problemas de historia literaria latinoamericana: periodización y categorías metodológicas afines", Letterature d'America 21 (Roma, 1984): 5-28; Juan Villegas, "La periodización literaria", Teoría de historia y poesta lírica (Ottawa: Girol Books, 1984), 17-40; y Ana Pizarro, ed. La literatura latinoamericana como proceso (Buenos Aires: CEDAL, 1985). 
determinada. Ortega y Gasset reduce a dos el número de atributos esenciales: coetaneidad, es decir, haber nacido dentro de una "zona de fechas", y la convivencia en un período determinado. Qué duda cabe que los nacidos dentro de una zona de fechas comparten experiencias comunes y responden a condiciones sociales que les dan una fisonomía propia. Usualmente se propone la medida de treinta años para señalar la sucesión generacional, cifra procedente de la genealogía, sin vigencia social. Para Ortega, sin embargo, la actividad histórica del ser humano dura treinta años, pero ese plazo se divide en dos etapas de aproximadamente quince años, en las cuales cambia el cariz de la vida. ${ }^{10}$ En 1977, Roberto Fernández Retamar reitera su adhesión al criterio de generación histórica, infrecuente apreciación entre intelectuales marxistas: "Debo decir que creo en su existencia, creo que en ellas se articula la historia, y creo también, pues de lo contrario me parecen sin sentido, en esa órbita sugerida por Ortega de aproximadamente quince años - no los que satisfagan al manualista de turno, ahora diez, ahora treinta"."11

No es fácil establecer la serie efectiva de generaciones históricas y de períodos literarios, especialmente en ámbitos de compleja densidad cultural. En el Uruguay contemporáneo, sin embargo, el momento en que se produce la transformación decisiva de valores estéticos y de inquietudes sociales es indudable: 1939. Este es, precisamente, el año en que Onetti publica $E l$ pozo y se funda el semanario Marcha, desde cuyas páginas pugnó por imponer una nueva sensibilidad en la literatura nacional. El semanario representa, además, el primer índice de un cuestionamiento radical de la conciencia social del país. Esta fecha marca el comienzo de un esfuerzo consciente de crear en el Uruguay una narrativa que rompa definitivamente con remanentes naturalistas y que responda a la sensibilidad universal dominante. Esta sería, entonces, la fecha de la generación decisiva del periodo considerado, punto de referencia para fijar las demás. Este esquema es, naturalmente, provisorio y debe ser corroborado - $\rightarrow$ rectificado-por el decurso real de la literatura.

Si se toma 1939 como punto de partida se tiene una hipótesis de trabajo. Los años clave para la narrativa uruguaya, en segmentos de quince años, serían: $1924,1939,1954,1969$. En efecto, la narrativa uruguaya contemporánea puede subdividirse en cuatro períodos que coinciden con la serie generacional, aun cuando tal esquema difiera considerablemente de las clasificaciones usuales, como se verá más adelante. 1) El período neonaturalista, al cual pertenecen los escritores nacidos entre 1887 y 1901 (José Pedro Bellán, Juan José Morosoli, Enrique Amorim, Francisco Espínola); 2) el período superrealista, de los narradores que nacen de 1902 a 1916 (Felisberto Hernández y Onetti); 3) el período neorrealista, formado por los nacidos entre 1917 y 1931 (Armonía

${ }^{10}$ Ortega y Gasset, En torno a Galileo, 69.

11 Roberto Fernández Retamar, Para una teorta de la literatura hispanoamericana (Caracas: Nuestro Tiempo, 1977), 141-142. 
Somers, ${ }^{12}$ Carlos Martínez Moreno, Mario Benedetti, José Pedro Díaz); 4) el período irrealista, de los nacidos entre 1932 y 1946 (Mario Levrero, Eduardo Galeano, Cristina Peri Rossi, Enrique Estrázulas). El concepto de período generacional debe ser usado con cautela, limitándosele a un papel auxiliar: si el esquema propuesto adquiere rigidez inquebrantable y se ajustan los cambios culturales a ese modelo abstracto, el concepto quedaría reducido a una mera etiqueta carente de significado. Esta periodización -que confiamos sea operacional y persuasiva-se limita a esclarecer los procesos de cambio literario en la narrativa uruguaya desde la primera posguerra en adelante. Evidentemente queda por demostrar si funciona en un periodo histórico más amplio y qué sucede con los otros géneros literarios.

\section{NEONATURALISMO}

Los escritores del período neonaturalista comienzan a publicar alrededor de 1924. A nivel hispanoamericano ésta es la generación que rompe con la tradición narrativa moderna e inaugura una nueva época de la literatura, la contemporánea. ${ }^{13}$ En el Uruguay, sin embargo, un renovado nacionalismo regionalista impulsa la tendencia nativista a la cual pertenecen los principales escritores del periodo, quienes asumen las normas del periodo precedente, mundonovista, en plena vigencia histórica. En rigor, la narrativa uruguaya del 24 es contemporánea por su cronología, no por el modo narrativo o la visión del mundo de sus obras.

El Uruguay de los años veinte era una sociedad agropecuaria medioburguesa y secularizada, poco propicia para rebeliones o disidencias; fueron años de apacible conformismo social en un clima cultural dominado por la personalidad y las ideas de José Batlle y Ordóñez. Desde la guerra civil de 1904, la revolución nacionalista del último caudillo gaucho, Aparicio Saravia, contra el gobierno de Batlle, hasta el golpe de estado del presidente Gabriel Terra el 31 de marzo de 1933 , consecuencia de la crisis financiera mundial de 1929, la organización social del país era estable y desarrollada. El ideario liberal progresista de Batlle,implementado en la Constitución de 1917 -gobierno ejecutivo colegiado, libertades públicas, avanzado sistema de seguridad social, nacionalización de las principales empresas, acceso de la clase media a la vida cívica- promovió la inverosímil convicción de vivir en un estado perfecto. Fue un factor estabilizador que produjo aparente justicia social, bienestar económico y confortable optimismo. El golpe de estado de 1933, comienzo de la polarización

12 Obviamente la edad no constituye un condicionante absoluto. Por su fecha de nacimiento (1914), Somers pertenece a la generacion anterior, pero literariamente gravita hacia la generación neorrealista y desconocer la individualidad del escritor sería un caso de aplicación mecánica y reductora del método.

${ }^{13}$ Goiç, Historia, 177-182. 
política, significó para el pueblo uruguayo, según Carlos Real de Azúa, "una fortísima conmoción de su confianza o de su indiferencia". ${ }^{14}$ Hasta entonces, el eco lejano de la primera guerra mundial, el desasosiego de posguerra ante el derrumbe de la civilización occidental y la turbulencia social del continente latinoamericano no repercuten en un país hedonista, de desmesurado desarrollo burocrático. Como bien dice Mario Benedetti: "en un país pequeño como el Uruguay, la estabilidad burocrática ha sido, desde el punto de vista de la creación artística, una suerte de banco de arena. Allí estamos encallados y no hay nueva ola capaz de conmovernos".15

Los factores determinantes del país condicionan una literatura desprovista de espíritu innovador que no siente la urgencia de experimentación expresiva y formal — con raras excepciones, como veremos. La modalidad dominante posee rasgos que le confieren una particularísima uniformidad que pone de manifiesto una sensibilidad generacional: el nativismo. La tendencia nativista, arraigada en la tierra y en los problemas de la vida campesina, persigue una finalidad documental y cognoscitiva. El nacionalismo literario, demasiado apegado a lo accidental para captar las dimensiones verdaderamente significativas de la realidad, dará una tónica restringida al período. Alberto Zum Felde, lúcido y polémico testigo de la época, ha descartado, con excesiva mordacidad, este proceso como un "fenómeno histórico de subdesarrollo cultural" que limita la literatura a "subliteratura regional"; y añade: "De aquel modo la literatura nacional no puede salir de su calidad de producción de consumo interno, pero no apto para la exportación. Categoría ésta que sólo puede lograrse por la universalidad del sentido y técnica de la obra". ${ }^{16}$

El nativismo constituye un movimiento cultural homogéneo que procura darle expresión artística a las modalidades del carácter y las costumbres del ambiente rural, afirmar la singularidad de un mundo nuevo; en su apogeo en la década de los veinte abarca poesía, narrativa, música y artes plásticas. ${ }^{17}$ En narrativa, los aspectos definidores de la tendencia nativista son, principalmente, dos: una temática común, apegada al ámbito campero, al cual supeditan todos los factores de creación artítica, y una uniforme postura literaria afín a la que desarrollaron los grandes novelistas de la generación mundonovista (José Eustasio Rivera, Rómulo Gallegos, Ricardo Güiraldes), tributaria, a su vez, del

\footnotetext{
${ }^{14}$ Carlos Real de Azúa, El impulso y su freno (Montevideo: Banda Oriental, 1964), 27.

${ }^{15}$ Mario Benedetti, Literatura uruguaya siglo XX (Montevideo: Alfa, 1963), 17.

${ }^{16}$ Alberto Zum Felde, Proceso intelectual del Uruguay 3 (Montevideo Ediciones del Nuevo Mundo, 1967), 15 y 20.

${ }^{17}$ La poesía de Fernán Silva Valdés y de Pedro Leandro Ipuche; la narrativa de Justino Zavala Muniz, Adolfo Montiel Ballesteros, Francisco Espinola, Enrique Amorim y Víctor Dotti; la música sinfónica de Eduardo Fabini y de Luis Cluzeau Mortet; la pintura de Pedro Figari, cuya primera exposición es de 1922. Sobre el nativismo, véase Arturo Sergio Visca, Aspectos de la narrativa criollista (Montevideo: Biblioteca Nacional, 1972).
} 
realismo-naturalismo decimonónico, que ya había agotado sus posibilidades creadoras.

La narrativa regionalista da una cuidadosa y verosímil representación espacial de la vida del hombre en estrecha relación con la naturaleza. El propósito esencial de los escritores más difundidos consistía en describir episodios supuestamente típicos y representativos de la vida rural, entendida como un proceso natural que se mueve a base de categorías lógicas, que requiere espacio y tiempo determinados y un ordenamiento causal, racional, cronológico y determinista de los hechos. De ahí el carácter anecdótico y episódico de novelas que buscaban reflejar una realidad fáctica, con el énfasis puesto en el desarrollo armonioso de una trama que tiene siempre una explicación satisfactoria, puesto que obedece a fuerzas espaciales o telúricas, a un orden social o a una tradición histórica explícita. Estas novelas pretendían dar una imagen del hombre en lucha con el medio ambiente y mostrar el efecto que éste producía en sus acciones; a través de la descripción ambiental, los cuadros pintorescos y el sabor nativo del habla dialectal procuraban descubrir lo autóctono del suelo americano. Al dársele excesiva importancia al examen de la relación del hombre con el ambiente telúrico - al "diálogo entre el hombre y la llanura", ${ }^{18}$ dice Amorim en El paisano Aguilar- se crearon personajes cuya interioridad anímica resultaba demasiado tipificada.

Los narradores más importantes del período (Amorim, 1900-1960, Espínola, 1901-1973, Morosoli, 1899-1957) dan categoría estética y significado social al espacio telúrico. La carreta (1932) y El paisano Aguilar (1934) de Amorim, Raza ciega (1926) y Sombras sobre la tierra (1933) de Espínola y Los albañiles de "Los Tapes" (1936) de Morosoli, son obras de indudable valor dentro de una corriente narrativa de escasa producción sobresaliente. Los tres, muy disímiles entre sí, trascienden las limitaciones del costumbrismo pintoresco, pero se mantienen al margen de las innovaciones expresivas y formales que se están produciendo en la literatura de aquel tiempo. Amorim es quien ha tenido mayor éxito internacional, pero Espínola es, sin duda, el más artista, el narrador de mayor intensidad y hondura humana. ${ }^{19}$

En el prólogo que Borges escribe en 1937 a la traducción alemana de $L a$ carreta señala que el "escritor de Buenos Aires o Montevideo que habla de gauchos, propende al mito - voluntaria o involuntariamente. Más de cien años de literatura anterior gravitan sobre él". La evocación nostálgica del pasado

\footnotetext{
${ }^{18}$ EnriqueAmorim, El paisano Aguilar (Buenos Aires-Montevideo: Ediciones de la Sociedad de Amigos del Libro Rioplatense, 1974), 304.

19 Junto a ellos merece destacarse Justino Zavala Muniz (1898-1968), autor de tres crónicas que recrean la vida rural desde la época gauchesca de fines del siglo XIX en adelante, con un propósito más histórico que literario: Crónica de Muniz (1921), Crónica de un crimen (1925) y Crónica de la reja (1930). Otros narradores de importancia local son: Yamandú Rodríguez, Juan Mario Magallanes, José Monegal, Adolfo Montiel Ballesteros y Pedro Leandro Ipuche, éste último más distinguido como poeta.
} 
marca a las obras cumbres hasta Don Segundo Sombra, culminación de la literatura gauchesca. Amorim no escribe al servicio de un mito, afirma Borges:

Amorim trabaja con el presente. La materia de sus novelas es la actual campaña oriental. [...] Le interesan -como a todo auténtico novelista-las personas, los hechos y los motivos, no los símbolos generales. [...] En las páginas de Amorim, los hombres y los hechos del campo están sin reverencia y sin desdén, con entera naturalidad -a veces con poética o atroz naturalidad..$^{20}$

La narrativa rural de Amorim, como la de Espínola y Morosoli, tiende a confirmar este temprano dictamen de Borges. Los tres pretenden dar una imagen verosímil y desmitificadora, comprender la miserable condición social del campesino, con recursos literarios semejantes. Amorim, de vasta y desigual obra, se mantiene en el plano de lo concreto y de la objetividad exterior; sobresale por la descripción del aislamiento y barbarie de los pobladores del norte uruguayo. Gran parte de su obra (no menos de 40 títulos) se resiente por debilidades de construcción, por esquematismos de caracterización y por el fuerte lastre ideológico que arrastra. Las dos novelas tempranas mencionadas en el párrafo anterior y la última publicada en vida, La desembocadura (1958), son sus obras más logradas, de equilibrado ensamblaje de historias costumbristas y realización artística. Morosoli, cronista de un mundo humilde, destaca por el áspero sabor vital de sus historias y por el carácter esencialmente documental y retratista de sus relatos; presenta actitudes típicas de la vida campesina (aislamiento, marginalidad, resignación) “de la manera más directa y simple posible", como observara Onetti, ${ }^{21}$ austero afán de autenticidad a la vez sugerente y desvaido. Con Espinola la tendencia nativista se revitaliza y llega a su cumbre; se cierra un ciclo que epígonos no han podido renovar ni superar. En sus cuentos (sólo 17), practica el díficil arte de la naturalidad; con sutileza estilística da más importancia a la atmósfera que a los sucesos, a las sensaciones que a las tramas, actitud poco frecuente en esta corriente narrativa. En Sombras sobre la tierra crea un vasto sistema de correspondencias entre el plano objetivo - la mísera vida en los bajos fondos pueblerinos-y el subjetivo - centrado en el divagar de la conciencia de seres desamparados, vistos con estremecida piedad - de eficaz formulación estética. Espínola supera el realismo costumbrista: al acentuar la dimensión interior de los personajes capta la verdad subjetiva que habita en el fondo de la conciencia de seres que así evitan caer en la condición de símbolos o arquetipos.

El nativismo dominante opacó la narrativa de asunto urbano, más acorde con el proceso de urbanización del país, que surge con esta generación y se

${ }^{20}$ Jorge Luis Borges, "Mito y realidad del gaucho", Marcha 775 (5 agosto 1985), 21.

21 Onetti, "Ha muerto Juan José Morosoli", Accion (Montevideo), 29 diciembre 1957, 4. Sin firma. 
consolida en los cincuenta, cuando la narrativa uruguaya alcanzó un carácter definitivamente urbano. Hay dos figuras de escasa difusión que, empero, merecen ser destacadas: José Pedro Bellán (1889-1930) y Manuel de Castro (1896-1919).

En la narrativa de Bellán la ciudad ya no es un simple telón de fondo (como en Carlos Reyles), sino un espacio conflictivo y mutilante. Su narrativa documenta conflictos de la primera década del siglo, en un Montevideo de evidente sensibilidad positivista: la beatería y la función represiva de la religión, la oposición amor ideal y sexual, el rechazo de la mujer intelectual (en El pecado de Alejandra Leonard, 1926, su "pecado" es ser inteligente).

La realidad(1922) es la nouvelle en la cual Bellán logra sus mejores resultados artísticos, con un acierto singular: es un relato interior de honda inmediatez humana en el que cuenta la disgregación emotiva de un hombre gris, hospedado en la pensión de Mme. Jourdain, con quien mantiene una apasionada relación sexual. El Señor X, así se le llama, sumergido en la anonimia urbana, relata una serie de sueños obsesivos con una mujer ideal, de quien se enamora en su imaginación. La realidad imaginada trasciende la vida cotidiana: se forma un estado de conciencia general que admite la existencia de Isabel, la mujer de sus sueños. Si bien el narrador es omnisciente, mantiene cierta ambigüedad respecto a la identidad de Isabel; renuncia a diferenciar entre la realidad (Isabel es la sobrina de un vecino que ve por la ventana de su cuarto), el sueño (la proyección del deseo de amor ideal), o un desdoblamiento síquico (la disociación del espíritu de Mme. Jourdain, "la una hace a la otra", ${ }^{22}$ acrecentandola angustia que el protagonista padece, en tanto desiste de toda determinación de la realidad. Cuando Mme. Jourdain se suicida, se desvanece su amor por Isabel; desaparece la situación conflictiva que nutre su historia - su relación degradante con la francesa- que busca superar con la imaginación, con la creación de una idealizada proyección de la realidad.

Manuel de Castro, autor de Historia de un pequeño funcionario (1928), en forma paralela a Roberto Mariani en Buenos Aires, con Cuentos de la oficina (1925), inicia un análisis realista de las oficinas públicas, de la mediocridad del mezquino mundillo burocrático montevideano. Su carácter de precursor de una línea narrativa que culmina treinta años después en Benedetti no ha sido suficientemente señalado, aun cuando su esfuerzo no alcance calidad estética perdurable.

La dicotomía ruralismo y urbanismo es, en rigor, una oposición falsa y simplista; toda clasificación temática subestima lo estrictamente literario, la función artística. Tanto en escritores de tema rural o urbano se advierten objetivos literarios comunes que definen una actitud generacional: la herencia del realismo y del naturalismo, en sus dos vertientes, la documental (rural) y la

${ }^{22}$ José Pedro Bellán, "La realidad" en El pecado de Alejandra Leonard y otros relatos (Montevideo: Arca, 1967), 75. 
sicológica (urbana). Los fundamentos esenciales de ambas tendencias derivan de fórmulas propias de la novela realista decimonónica, cuyas características específicas dependen de un postulado básico: la existencia de un mundo fenoménico sometido a la observación directa y al conocimiento sensorial, captable a base de experiencias personales..$^{23}$

La estructura cronológica lineal, la narración subordinada a un suceso, el orden secuencial lógico que exige relaciones de causa y efecto, el apego a detalles concretos y veristas, la caracterización detallada, el predominio de un lenguaje llano, denotativo y discursivo, la inclinación del narrador a documentar las costumbres del ambiente con cuadros pintorescos, la tendencia a la objetividad y a explicitar el sentido, la esquematización de las situaciones, la toponimia real e histórica y la forma analítica de describir al hombre, condicionado por el medio ambiente, son remanentes del realismo-naturalismo decimonónico, del afán de representar un mundo verosímil -ya sea rural o urbano. No puede sorprender, entonces, que no se aspire a ir más allá de lo fenoménico, a abolir los órdenes previstos, a descubrir dimensiones menos explícitas, no comunicables por via racional. El lenguaje se vuelve transparente para dar la ilusión de conocimiento directo de la realidad y desempeña un papel funcional, sin adquirir importancia en sí. La univocidad del signo neutraliza las propiedades del lenguaje de hacer posible una comunicación ambigua y no natural de lo representado. El narrador de la generación de 1924 quiere contar historias, recrear episodios verosímiles del mundo cercano en formas sencillas.

Por los mismos años, y en forma paralela, se desarrolla en Hispanoamérica el vanguardismo cosmopolita, que impugna los presupuestos estéticos mundonovistas y rompe deliberadamente con la tradición inmediata. En el Uruguay la vanguardia experimental tuvo atenuada repercusión, sin dejar obras notables. ${ }^{24}$ "Falta a nuestra vanguardia de los años veinte y aun de los treinta," observa Martínez Moreno, "esa estridencia propia de las renovaciones raigales de las grandes propuestas transformadoras". ${ }^{25}$ Las revistas que congregan a la juventud no eran polémicas: Los Nuevos, La Cruz del Sur, La Pluma yCartel divulgan figurasimportantes de los vanguardismos europeos sin animar mayormente la plácida vida cultural. Zum Felde, director de La Pluma,

${ }^{23}$ Wolfgang Kayser, "Origeny crisis de la novela moderna", Cultura Universitaria 47 (1955), 36 .

${ }^{24}$ Hugo J. Verani, Las vanguardias literarias en Hispanoamerica (Roma: Bulzoni, 1986); y, especialmente, José Pedro Díaz, "Las Letras", y Hugo Achugar, "Letras. La década del veinte: vanguardia y batllismo. El intelectual y el estado", en Vida y cultura en el Rio de la Plata (Montevideo: Dirección General de Extensión Universitaria, 1987), tomo I, 87 97 y $99-116$, respectivamente.

${ }_{25}$ Carlos Martínez Moreno, "Las vanguardias literarias", Enciclopedia uruguaya 47 (Montevideo: Editores Reunidos, 1969), 124. 
destaca el "discreto eclecticismo convencional característico" de todas ellas: "ninguna era, francamente, órgano de batalla" ${ }^{26}$

Existió, sin embargo, un narrador sin lectores y al margen de todo movimiento, cuya influencia no ha cesado de crecer: Felisberto Hernández (1902-1964). ${ }^{27}$ Son los años de aprendizaje de un escritor sin antecedentes que cultiva una narrativa imaginativa, de límites imprecisos entre loreal, lo surreal y lo fantástico, modalidad radicalmente opuesta al nacionalismo regional. Felisberto está en el linde generacional y podría ser situado tanto en esta generación como en la siguiente, hacia la cual gravita, en gran parte por publicar sólo sus tanteos primerizos entre 1925 y 1931, cuatro breves cuadernos, y no volver a hacerlo hasta 1942. Su narrativa representa la apertura a un nuevo período generacional y se afirma cuando cambian las relaciones entre literatura y sociedad, cuando prima la noción de literatura como realidad de ficción.

\section{FUNDADORES DE LA NUEVA NARRATIVA}

A partir de los años treinta una nueva sensibilidad artística -más imaginativa, más experimental_ prevalece en la literatura contemporánea. La narrativa uruguaya e hispanoamericana adopta una faz enteramente nueva: será un acto de creación antes que de representación, que interesa más por el despliegue imaginativoy por la funcionalidad interna de los elementos narrativos que por su carácter representativo de una realidad preexistente. Es un período fecundo en fuerzas renovadoras, de síntesis de tendencias diversas que se funden en una, el surrealismo, que trae una liberación de la imaginación creadora y del lenguaje, una apertura hacia zonas desconocidas del yo, una actitud elusiva de narrar que genera una subjetivación de la creación artística, una vía de acceso a un mundo onírico o fantástico inmune a las categorías racionales dominantes en el mundo de los hechos reales.

Las formas portadoras de cambio surgen, observa Miklos Szaboloscsi, en comunidades que "muestran un desarrollo social, unaeconomía y una civilización estancados, es decir, aquellos países donde la revolución artístico-intelectual reflejaba un descontento social”. ${ }^{28}$ De hecho los acontecimientos históricos que

${ }^{26}$ Zum Felde, Proceso intelectual, 13. Los Nuevos, 1-5, 1919-1920; directores: Indefonso Pereda Valdés y Federico Morador. La cruz del sur, 1-34, 1924-1931; fundador Alberto Lasplaces. La Pluma, 1-19, 1927-1931; director: Alberto Zum Felde. Cartel, 1-10, 1929 1931; directores Julio Sigüenza y Alfredo Mario Ferreiro.

${ }^{27}$ Otros dos narradores vanguardistas dejaron obra menor: el poeta Ildefonso Pereda Valdés, con El sueño de Chaplin (Montevideo: Editorial Río de la Plata, 1930); y Luis Giordano, con Luciano y los violines (Montevideo: La Cruz del Sur, 1930). En los veinte, Giordano fue considerado el escritor más representativo de la vanguardia literaria del Uruguay; véase, Antología de narradores del Uruguay, edición de Juan M. Filartigas (Montevideo: Editorial Albatros, 1930).

${ }^{28}$ Miklos Szabolscsi, "La 'vanguardia' literaria y artística como fenómeno internacional", Casa de las Américas 74 (1972), 10. 
condicionan el cambio de sensibilidad generacional se van revelando a partir de la inestabilidad que trajo la crisis institucional de 1933; la repercusión de problemas internos - la progresiva escisión política que culmina en otro golpe de estado, el de Alfredo Baldomir (1942) — y los efectos de conflictos mundiales - la guerra civil española y los fracasos de los frentes populares, la segunda guerra mundial y la amenaza del fascismo- aglutinan a los intelectuales y disuelven rápidamente la fatuidad optimista. Hacia 1939, se hizo tangible el estancamiento y el deterioro de un sistema social hostil al cambio, que había dejado de producir efectos positivos. Tras un período apacible y civilista sigue otro de inseguridad y de precariedad social, de ruptura del orden institucional. El hondo desasosiego ante una civilización trastornada y la amenaza de un desmoronamiento social repercute en escritores que creen en cánones estéticos muy diferentes. A partir de ese año clave comienzan a organizarse nuevos medios de comunicación que sirven de tribuna a las inquietudes que acucian a jóvenes marginados del orden social, que desconfían de formas estatuidas. Es incuestionable el papel preponderante que cabe al semanario Marcha en el proceso de revisión histórica y cultural del país. Fundado por Carlos Quijano el 23 de junio de 1939, con Onetti de secretario de redacción, el aporte del semanario en la formación de una conciencia nacional como tarea colectiva, a través de esquemas provenientes de ideologías socialistas, ha sido ya debidamente señalado..$^{29}$

La consecuencia de todo esto - y lo que caracteriza a esta generación-es el inconformismo de escritores que trascienden cualquier ortodoxia y rechazan toda noción preconcebida, que establecen una ruptura radical y definitiva con la postura literaria y el sistema de valores precedentes. Onetti sintió como propia la misión de plantearse el problema del estancamiento de la literatura uruguaya ("Ta ostensible depresión literaria que caracteriza los últimos años de la actividad nacional"), ${ }^{30}$ atribuyéndose el deber de constituirse en beligerante voz crítica. "La piedra en el charco", columna literaria que escribe en Marcha de 1939 a 1941, para despertar de su letargo al ambiente local, fue la primera manifestación del descontento y sirve de manifiesto o proclama generacional. Con fervor inusitado rechaza el aplastante provincianismo de un mediocultural desprovisto de estímulos para el nuevo escritor: "No hay aún una literatura nuestra, no tenemos un libro donde podamos encontrarnos" (18); se necesita una voz "capaz de volver la espalda a un pasado artístico irremediablemente inútil" (19); "vivimos la más pavorosa de las decadencias. [...] Estamos en pleno reino

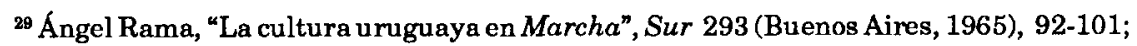
Hugo Alfaro, Navegar es necesario: Quijano y el semanario Marcha (Montevideo: Banda Oriental, 1984), y Pablo Rocca, “35 años en Marcha” Nuevo Texto Critico, II (1993), en prensa.

${ }^{30}$ Onetti, Réquiem por Faulkner y otros artículos, edición de Jorge Ruffinelli (Montevideo: Arca/Calicanto, 1975), 16. Las diez citas siguientes se hacen de esta edición. 
de la mediocridad" (30). Son notas cáusticas que invitan la polémica y aspiran a agitar un ambiente conformista y acartonado, dominado por epígonos del telurismo campero. Consciente de las limitaciones de una narrativa que aún continuaba estrechamente vinculada a corrientes estéticas que habían completado su ciclo, Onetti define sü propio contorno generacional a través de su experiencia de lector. Sólo una novela de la generación anterior, "aún no superada entre nosotros" (61), merece su elogio: Sombras sobre la tierra. Los demás escritores son "plumíferos sin fantasía, graves, frondosos, pontificadores con la audacia paralizada" (30).

La importancia de las notas críticas que Onetti escribe entre 1939 y 1941 reside en que en ellas formula su drástico cuestionamiento a la tradición inmediata, animado por el fervor de una nueva relación con la literatura, en una especie de dilatado manifiesto, o, más bien, de autoafirmación en cuanto escritor. En esas páginas inicia la lucha contra la mediocridad de un medio carente de inquietudes que renueven el curso de la literatura: "Esto induce a pensar en un país fantástico en que de pronto hubiera desaparecido la juventud y el reloj de la vida siguiera dando siempre una idéntica hora" $(16)$. Esboza un credo estético que obedece al afán de vivificar las letras nacionales, imponiéndose horizontes distintos ("defender la necesidad de no imitar a nadie") (57). Insiste en la urgencia de interiorizar las experiencias narradas ("que cada uno busque dentro de sí mismo") (43); defiende una temática ciudadana ("la ciudad que estamos viviendo es de una riqueza que pocos sospechan") (28); reitera la necesidad de una renovación formal de la narrativa ("expresarse con una técnica nueva, aún desconocida [...] intransferible, única") (44), sin llegar a convertir la técnica en el asunto central de la creación.

Son notas dedicadas casi exclusivamente a la literatura, desinteresadas de inquietudes sociales o políticas, subjetivismo individualista que dará fisonomía propia a la generación. Onetti sólo asume una responsabilidad literaria ( $\mathrm{El}$ único compromiso que acepto es la persistencia de tratar de escribir bien y

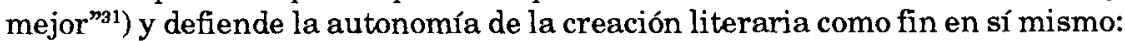
"Creemos que la literatura es un arte. Cosa sagrada, en consecuencia: jamás un medio sino un fin". ${ }^{32}$ La postura de Onetti, como se verá, es radicalmente opuesta a la de la generación siguiente, la de Benedetti y Martínez Moreno, que proclama el compromiso social del escritor.

Por esos mismos años el credo literario de Onetti cristaliza en sus primeras obras de indiscutible valía: El pozo (1939), "Un sueño realizado" (1941) y Tierra de nadie (1941). Ángel Rama afirma que "son prácticamente los manifiestos de una generación aislacionista, que en oposición a la entrega pública y militante de los mayores reasume la subjetividad, la soledad, la atención casi excluyente

31 "Encuesta entre escritores nacionales", El Popular (Montevideo) 26 enero 1962, Suplemento, 4.

32 Onetti, "Divagaciones para un secretario", Accion, (24 octubre 1963), 19. 
por el arte".33 Onetti inventa un mundo desolado de progresiva plenitud imaginativa en el que reordena las tensiones existentes en la vida contemporánea (alienación, incomunicación, corrupción moral, sordidez, etc.) en construcciones verbales autosuficientes que desmitifican la propia condición humana. La autorreflexividady la multiplicidad de perspectivas narrativas que se desmienten entre sí, marcan el comienzo de una literatura que toma conciencia de sí misma. En forma casi paralela, reaparece Felisberto Hernández con obras decisivas Por los tiempos de Clemente Colling (1942) y El caballo perdido (1943)-que reflejan una atormentada vida interior mediante una escritura discontinua, fragmentada y anómala, que responde a la fascinación por lo onírico y lo fantástico.

Evidentemente, la narrativa de este período no tiene ya más una función cognoscitiva, un apego emocional a la patria chica, rural. Es una narrativa antirrepresentacional, que difumina el contorno inmediato y postula el relato como universo imaginario y mitopoyético.

Felisberto y Onetti asumen una actitud de radical ruptura con la tradición nacional y esta voluntad de diferenciarse de la narrativa neonaturalista representa la sensibilidad peculiar de la generación. La afinidad entre ambos no procede de compartir preceptos estéticos, sino de convivir en un ámbito condicionado por un sistema de normas que rechazan y, ante todo, por el cariz imaginativo que adquiere su narrativa.

Ambos recogen las inquietudes del momento y responden de modo distinto a los apremios de una realidad mutilante, pero adoptan una misma actitud frente a la creación literaria: abandonan la visión simplista y documental de lo real concreto e inician una actividad imaginativa que privilegia las ilimitadas posibilidades de la ficción, más efectiva cuanto mayor es la correlación entre lo interior y lo exterior. José Pedro Díaz subraya esta semejanza generacional entre Felisberto y Onetti:

las diferencias que los separan y aún los elementos mismos que más los caracterizan y creo que son precisamente los que los hacen contrastar, responden, según creo, a una motivación común, al momento histórico que vivieron en nuestro país, a la práctica social que nuestra situación histórica nos impuso, y que en cada uno de ellos motiva características que, si bien son diferentes, vienen en definitiva a converger en un efecto común que es en cierto modo antinovelístico: un evidente desapego a lo real, la voluntad de hacer prevalecer el timbre propio de lo imaginario, sea recuerdo, sea invencion..$^{34}$

Estecierto modo antinovelístico(Díaz sólo desarrolla el tema del espectáculo) o, más bien, el desdén por las normas de lo bello y lo estético, está implícito en una de las piedras en el charco que lanzara Onetti, propuesta como pauta

${ }^{33}$ Ángel Rạma, La generación crítica 1939-1969 (Montevideo: Arca, 1972), 123.

${ }^{34}$ José Pedro Díaz, El espectáculo imaginario (Montevideo: Arca, 1986), 15. 
generacional: "la verdad tiene que estar en una literatura sin literatura". ${ }^{35}$ Muchos años después, Cortázar reitera que lo importante en nuestro tiempo es este despojamiento antiliterario: "la negativa a mediatizar, a embellecer, a hacer literaturan. ${ }^{36}$

El lenguaje antiliterario, supuestamente espontáneo y confesional del primer Onetti es un modo eficaz de proyectarse hacia la interioridad, de buscar naturalidad expresiva sin mediatizar, sin hacer literatura. Sobresale la evocación de experiencias subjetivas, sin secuencias lógicas, la percepción fragmentaria de la realidad y el discurso figurado, irreductible a términos genéricos. En sus novelas de madurez predomina la prosa lírica y lúdica, consciente de sus ambigüedades propias, el discurso conjetural y las versiones equívocas de los hechos. En una trama aparentemente realista, Onetti inserta planos imaginativos, evocaciones, sueños y ensueños que desplazan casi por completo a la descripción y a la acción novelesca. La novela tradicional (descriptiva, espacial y esteticista) se convierte con Onetti en la novela de ámbitos oníricos escurridizos, de escritura ambigua, rica en sugerencias y tensiones conflictivas.

Una actitud antirretórica aún más marcada se comprueba en los relatos de Felisberto. La narración torpe y espontánea, que él mismo ha calificado de "lenguaje sencillo de improvisación [...] lleno de repeticiones e imperfecciones que me son propias" ${ }^{37}$ es un modo de escribir que acoge cualquier incitación que lo active. El discurso fragmentado y digresivo de Felisberto, deliberadamente discontinuo, responde a un pensamiento disociativo, a una lógica de la incongruencia y de la heterogeneidad. Las inusitadas relaciones entre seres y cosas, entre lo animado y lo inanimado, y la inversión de sus atributos, disuelve órdenes irreconciliables, problematizando agudamente la noción de escritura. Tanto Felisberto como Onetti focalizan el relato en el acto de escribir, tendencia autorreflexiva que implica una práctica escritural como fabricación más que como representación de la realidad: "Es cierto que no sé escribir pero escribo de mí mismo", "No sé si esto es interesante, tampoco me importa," dice Eladio Linacero en $E l$ pozo; ${ }^{38}$ "Ha ocurrido algo imprevisto y he tenido que interrumpir esta narración", "Me he detenido de nuevo. Estoy muy cansado", se lee en $\mathrm{El}$ caballo perdido. ${ }^{39}$ Esta toma de conciencia literaria señala claramente el rechazo de la retórica, la desconfianza con el acartonamiento o la solemnidad académica que perjudicaba la literatura de entonces. Revela, en fin, una falta de respeto por las normas de escribir de la cultura oficial.

\footnotetext{
${ }^{35}$ Onetti, Réquiem por Faulkner, 44.

${ }^{36}$ Julio Cortázar, "Situación de la novela", Cuadernos Americanos 4 (1950), 233.

${ }^{37}$ Felisberto Hernández, Obras completas, edición de José Pedro Díaz (Montevideo: Arca, 1983), tomo 3, 213.

${ }^{38}$ Onetti, El pozo (Montevideo: Arca, 1965), 7 y 20.

${ }^{39}$ Felisberto Hernández, El caballo perdido (Montevideo: Arca, 1970), 26 y 32.
} 
No puede sorprender que la producción de los escritores de este período generacional sea exigua en sus años formativos. Como los grandes escritores anteriores (Eduardo Acevedo Díaz, Javier de Viana, Florencio Sánchez, Horacio Quiroga, Amorim), Onetti y Felisberto dependieron del medio cultural y editorial de Buenos Aires. La falta de editoriales y de público lector en el Uruguay obligó a Felisberto a publicar en ediciones caseras, "libros sin tapas", toda su obra anterior a 1947, año en que Sudamericana de Buenos Aires acogió Nadie encendía las lámparas. Onetti imprimió El pozo con dos amigos, en papel estraza, y publicó prácticamente toda su obra hasta 1959 en Buenos Aires. Es muy posible que estas precarias condiciones editoriales y la falta de estímulos culturales impidieran que otros escritores innovadores, por naturaleza minoritarios, publicaran sus obras.

Un caso extremo y ejemplar es L. S. Garini, 1903-1983, escritor de extraña originalidad, de vocación narrativa muy tardía, que escapa a todo esquema: publica su primer libro, Una forma de la desventura (1963), entrando ya en la vejez. Por ello no tuvoincidencia en su generación y fue relegado cuando publicó en ediciones de escasa circulación. Su obra es un caso convincente de que la fecha de publicación de un libro es un detalle circunstancial. Se le incluye por lo común en antologías de "los nuevos", escritores que se inician a partir de 1960. Sin embargo su narrativa está fuertemente determinada por su filiación generacional: es otro ejemplo de la poética antirrepresentacional y del hastío de la literatura que distinguen a la generación de 1939.

Garini practica una literatura imaginativa que privilegia la dimensión fantástica, irracional y absurda de lo cotidiano, con un fuerte aire de familia con Felisberto, su estricto coetáneo; a él se asemeja por el estilo desaliñado y reiterativo, la sintaxis despojada y la cautivante ingenuidad. Las extravagancias estilísticas (el abuso del etc., de la "o" disyuntiva, de las comillas y de los gerundios) demuestran la desconfianza con las normas estéticas. El lector es atraído a un mundo desconcertante que desmiente la sencillez de una escritura privada de toda cualidad informativa, que trasluce el estado desordenado de una conciencia enajenada. Sus relatos son alegorías de un mundo desolado, de las desventuras de hombres humillados que callejean en busca de alojamiento, comida o empleo. Mediante sucesos disparatados y de inusual inventiva plantea situaciones inéditas en la literatura: el robo de una casa visto desde la perspectiva de un gato herido, un colchón "desprestigiado", un mal corte de pelo, personajes apremiados por urgencias impostergables (orinar, defecar), que se defienden contra insectos invisibles que invaden el cerebro o padecen amenazas que no comprenden, etc.

Giselda Zani (1909-1975) es un caso semejante, aunque menor. Se dio a conocer como poeta en 1930 y muy tardíamente publicó su único libro, Por vínculos sutiles (1958), cuentos fantásticos que iluminan zonas oscuras de una realidad atravesada por la mágica presencia del más allá. Zani transfigura el contorno introduciendo lo insólito y lo sobrenatural en lo verosímil: "La casa de la calle Socorro" es un relato de indudable calidad artística. 
Las tendencias o movimientos literarios no desaparecen abruptamente sino que afectan a uno o varios períodos. La emergencia de una nueva sensibilidad no impidió, como es natural, que convivieran con ella estéticas disímiles. La narrativa nativista dio muestras de agotamiento estético, pero se continuó en este período. Entre los ejemplos epigonales más importantes están Santiago Dossetti (1902-1981), Víctor Dotti (1907), Eliseo Santiago Porta(19121971) y Serafín García (1908). Alfredo Gravina (1913) se inició como narrador campero, para desviarse muy pronto hacia la narrativa proletaria, con un realismo socialista de escasa fortuna. La literatura social no desempeñó más que un papel secundario entre los escritores de esta generación, y el tiempo va borrando sus nombres. Clara Silva (1905-1976), de mayor importancia, perosin dejar novelas plenamente logradas, combina formas tradicionales con una temática contemporánea; denuncia la alienación de la mujer en la sociedad y la delincuencia juvenil en prosa de densidad ensayística, sobrecargada de interrogantes metafísicos y angustia existencial. Esta tónica testimonial, de índole moral más que social, emparenta la narrativa de Clara Silva con los enfoques básicos de la generación siguiente.

\section{NARRATIVA SOCIAL}

Si de 1924 a 1939 hubo un desplazamiento radical de sensibilidad artística y cultural, de 1939 a 1954 hay una aparente continuidad de lineamientos rectores, una consolidación de creencias y de planteos ideológicos. La práctica narrativa revela, sin embargo, una considerable distancia entre ambas generaciones. Como se ha visto, la orientación dominante de la generación de 1939 privilegia una aventura interior excluyente, enlazada con tendencias surrealistas o fantásticas; por el contrario, la generación de 1954, la de Benedetti y Martínez Moreno, se fundamenta sobre una diferente noción de la literatura; tiende a particularizar comportamientos humanos en contextos urbanos concretos, con un fuerte propósito ideológico. Hay un cambio de preferencias artísticas, de condiciones sociales de la producción y de la recepción de la literatura. La creciente presión de los conflictos sociales condiciona la transformación de la literatura y la subordinación de las pautas hasta entonces vigentes: la indagación en zonas inéditas de lo imaginario y la invención de espacios ficticios regidos por leyes propias.

Dos libros de los críticos por excelencia de la generación, Ángel Rama y Emir Rodríguez Monegal, estudian con lucidez el proceso cultural del país en este período; ambos siguen siendo trabajos de consultaindispensables..$^{40}$ Para designar de un modo global a los escritores del medio siglo Rodríguez Monegal populariza la designación de "generación del 45"; Rama propone, en cambio, el rótulo de

${ }^{40}$ Emir Rodriguez Monegal, Literatura uruguaya del medio siglo(Montevideo: Alfa, 1966), y Ángel Rama, La generación critica, ya citado. 
"generación crítica", por el signo dominante de la cultura del período. Ambas denominaciones se han hecho de uso generalizado y alcanzaron carácter casi oficial. Si bien es cierto, como dice Rama, que la fórmula generación del 45 carece de "fundamento razonado" ${ }^{41}$ el nombre de generación crítica exige ciertas precisiones. La periodización de Rodríguez Monegal no se ajusta a los hechos literarios; da primacía al grupo de escritores que hace su aparición pública hacia 1945 , cuyas primeras publicacionescal ternan con la obra de escritores que están llegando a su madurez y predominio histórico, a quienes también incluye en la supuesta generación del 45 (por ejemplo, Onetti, que publica desde 1933). Se da énfasis a una fecha en torno de la cual giran los propios intereses de Rodríguez Monegal - fue el año en que comenzó a dirigir la sección literaria de Marchacolocando en un mismo nivel histórico a escritores de muy distintas edades y etapas de formación cultural. Rama fundamenta de modo más convincente su periodización; toma como linde generacional los treinta años transcurridos entre 1939 y 1969, considerado como un solo período, dividido en dos promociones. Aunque los límites históricos coincidan, la clasificación que propongo difiere considerablemente de la de Rama. Nuevamente se asimila a Benedetti y otros jóvenes que se incorporan a las letras en los cuarenta a escritores mayores (otra vez Onetti), que responden a impulsos distintos. Para Rama, la "concepción realista, comprometida y sociologista, signó la obra narrativa desde el inicial Onetti hasta Benedetti" ${ }^{42}$ Las diferencias de formación cultural y de intereses literarios entre ambosson demasiado notorias para aceptar este emparejamiento. Atendiendo al proceso cultural de la sociedad, como hace Rama, no hay hiato visible y sí la progresión de una misma voluntad..$^{43}$ Lo hay, en cambio, en el proceso narrativo. La corroboración de tal ruptura se encuentra en el cotejo de las afinidades y diferencias entre dos generaciones con un perfil bien definido: la de 1939, universalista y surrealizante, y la de 1954, nacionalista y neorrealista. La obra de Benedetti y Martínez Moreno revela claramente la redefinición de la función de la literatura; se distingue por acentuar situaciones de significado social, en abierta oposición con la preocupación esencialmente literaria de sus predecesores. De hecho, no se trata de una misma generación desdoblada en dos fases, sino de dos generaciones que pugnan por imponer una nueva sensibilidad bajo condiciones históricas distintas.

Es indudable que hacia el medio siglo una nueva generación emerge en la escena nacional. Exceptuando los inevitables libros de poemas, los narradores de este período no comienzan a publicar con regularidad hasta la década de los cincuenta, para dar a conocer sus obras más importantes en los sesenta. En su fase de preparación todos ellos son reticentes frente al compromiso político, actitud acorde a la generación anterior, a cuyos estímulos está naturalmente

\footnotetext{
${ }^{41}$ Rama, La generación crítica, 135.

${ }^{42}$ Rama, 53.

${ }^{43}$ Rama, 20.
} 
sometida. Las revistas que fundan, Clinamen, Escritura, Marginalia, Asir y Número son casi exclusivamente literarias.4 "Todas ellas," dice Rama, "de nítida impronta literaria con muy escasa o nula inquietud por los temas sociales o políticos" ${ }^{45}$ Asiry Número, las másimportantes, son los voceros de lageneración. La bipolaridad cultural que distingue a la literatura uruguaya - criollismo y cosmopolitismo- se manifiesta en dos revistas con concepciones estéticas radicalmente antagónicas, que representan las dos tendencias dominantes en que se escinde el periodo generacional. Asir concede preferencia a la valoración de la tradición nacional, especialmente la narrativa campera, con desdén por la novedad literaria. Número, la revista más influyente, es el polo opuesto: prescinde de todo nacionalismo, introduce las nuevas corrientes estéticas, concentrándose en la crítica literaria con inusual exigencia.

El perfil definitivo del período empieza a vislumbrarse cuando cambia el clima social y se agudizan las tensiones políticas. Es un ejemplo evidente de la honda acción dialéctica del cambio social en la transformación del hecho literario. A partir de 1955 se ha ido acentuando la crisis económica y el descontento popular. El proceso definitivo de estancamiento de un sistema político culmina en las elecciones de 1958 con el cambio de gobierno; después de 93 años de poder ininterrumpido, el Partido Colorado es derrotado por el Partido Nacional. "Hemos llegado," dice Real de Azúa, "a ser una sociedad económicamente estancada, políticamente enferma, éticamente átona" ${ }^{46}$ Casi simultáneamente, la revolución cubana de 1959 conmueve a los intelectuales del país ("un país de espaldas a América"47), que por primera vez se sienten partícipes del destino de América Latina, cuyoimpactorepercute inmediatamente hasta en la ficción (por ejemplo, El paredón, 1963, de Martínez Moreno). Por esos años, además, la teoría del compromiso social formulada por Sartre impulsa a buen número de escritores a buscar una justificación ética oideológica a su obra. Evidentemente, todos estos condicionantes sociales tienen profundas repercusiones culturales y van marcando la obra de escritores de progresiva radicalización ideológica, cuya consecuencia más visible es la subordinación de lo artístico a lo social. El caso más notorio es el de Benedetti, que en 1960, con El país de la cola de paja y La tregua, "abandona la literatura elitista, ácida e intelectual que venía haciendo y se incorpora plenamente a la problemática del

4 Clinamen, 1-5, 1947-1948; director: Ángel Rama. Escritura, 1-10, 1947-52; directores: Julio Bayce, Carlos Maggi, Hugo Balzo. Asir, 1-39, 1948-1959; directores: Washington Lockhart, Domingo Bordoli y Marta Larnandie de Klinger. Marginalia, 1-6, 1948-1949; director: Mario Benedetti. Número, 1-27, 1949-1955; $2^{\text {e }}$ época, 1-4, 1963-1964;directores: Manuel A. Claps, Rodríguez Monegal, Idea Vilariño; más adelante se agregan Benedetti y Martínez Moreno.

${ }_{45}$ Rama, La generación critica, 58.

${ }^{46}$ Real de Azúa, El impulso y su freno, 106.

${ }^{47}$ Benedetti, Literatura uruguaya, 12. 
país". ${ }^{48}$ Asir y Número cierran en 1955 (ambas reaparecen años después) y tal vez no sea casual que las revistas que surgen ese mismo año ya no sean literarias: Nexo, Nuestro tiempo y Tribuna universitaria están dedicadas a las ciencias sociales, a diagnosticar la descomposición social del Uruguay. ${ }^{49}$ La sección literaria de Marcha, barómetro cultural del país, registra, precisamente, este cambio de actitud. En sus dos etapas más importantes fue dirigida, como es sabido, por Rodríguez Monegal (1945-1957) y por Ángel Rama (1958-1968): dos modos antagónicos de encarar la crítica literaria. Rodríguez Monegal asume la labor de introducir a grandes escritores de la literatura universal y a promover la consideración estética de la obra literaria, acentuando ante todo sus valores literarios. Rama, por el contrario, se adhiere a la posición que asume su generación en su madurez: el reconocimiento de la función social del crítico y el desarrollo de una perspectiva cultural latinoamericana, situandoa la literatura en un contexto ideológico.

La crítica literaria canalizó la actitud revisionista de esta generación. Hacia 1954 una apasionada conciencia cultural, polémica e hipercrítica se convierte en la constante generacional: restauran la crítica exigente, fundan editoriales y revistas especializadas, dinamizan el periodismocultural y preparan al público en el conocimiento de la literatura universal. Los principales animadores y promotores (Benedetti, José Pedro Díaz, Ángel Rama, Real de Azúa y Rodríguez Monegal) lograron el reconocimiento internacional. Acallado Zum Felde, les correspondió a ellos traer una crítica lúcida e informada.

A partir de 1960 se dan por primera vez las condiciones esenciales para la labor literaria: surgen editoriales (Alfa, Arca, Asir, Banda Oriental) que promocionan el libro nacional y lo convierten en producto de alto consumo. Gracias a la creciente avidez de lectura del público - paradójicamente en época de feroz crisis económica- las ediciones comerciales sustituyen a la común edición de autor y en sólo ocho años (de 1959 a 1967) la venta promedio de libros humanísticos subió de cincuenta mil a quinientos mil por año. ${ }^{50}$ El auge de la narrativa hispanoamericana (son los años del boom continental) repercute en la inusitada recepción del producto local. La mayor diversidad de estímulos a la creación literaria nacional se refleja en la consolidación artística de la obra de escritores de diversas generaciones. Es, sin duda, la década de mayor actividad intelectual que ha conocido el pais; fecundidad y ductilidad signan a

${ }^{48}$ Rama, "El boom editorial", Marcha 1385 (29 diciembre 1967), 2" sección, 3.

${ }^{49}$ Rubén Cotelo, "El signo de los nuevos es la muerte del joven brillante", Marcha 1189, (27 diciembre 1963), 5.

${ }^{50}$ Carlos Maggi, Sociedad y literatura en el presente: el boom editoral, Capítulo Oriental 3 (Montevideo: CEDAL, 1968), 40-41. Benedetti resume las dificultades de profesionalización del artista: "Hasta mediados de 1960, todo escritor uruguayo sabía que prácticamente la única posibilidad de publicar un libro era financiarlo de su propio bolsillo"; Literatura uruguaya, 23. 
los escritores de esta generación (en algunos casos, como Benedetti, no hay género literario que no hayan practicado). La coexistencia de tendencias en conflicto, la superposición de las generaciones convivientes y en plena actividad (no hay que olvidarse que son los años en que Onetti y Felisberto logran ser difundidos continentalmente), le dan densidad cultural a este periodo de la literatura uruguaya como a ningún otro.

En plena eclosión del experimentalismo en Hispanoamérica, los narradores de la generación de 1954 se desenvuelven dentro de un neorrealismo de escasa preocupación formal. El interés en crear un estrecho vínculo entre la obra y el público se revela en la inmediatez de lo contado y en la transparencia de un lenguaje funcional, acorde con el desarrollo anecdótico de los relatos. Benedetti (1920) reivindica la literatura comunicativa, legible por el hombre común. En su madurez, escribe sobre las idiosincrasias de la clase media urbana, los oficinistas y otros tipos montevideanos sumidos en la mediocridad de la rutina burocrática, con un lenguaje simple y directo, minado de ironía. Montevideanos (1959), La tregua (1960) y Gracias por el fuego (1965) son libros clave de la generación. Progresivamente, su mirada inconformista lo lleva a denunciar injusticias de una sociedad desilusionada y a abrirse al contorno latinoamericano, adaptando su literatura a consignas políticas que se traducen cada vez más en esquematismos simplificadores. Martínez Moreno (1917-1986) relata con afán totalizador y discursivo la declinación de una sociedad en quiebra, desmitifica la imagen idilica y patriarcal del país desde el patriciado a la guerrilla urbana. Con las primeras luces (1966), su novela de mayor eficacia expresiva, resume las virtudes de su quehacer creador. Partes de naufragio (1969) de José Pedro Díaz (1921) es la alegoría del derrumbe nacional, lúcida reconstrucción de un tiempo abolido, el Montevideo burgués entre 1920 y 1960 . Armonía Somers (1914) es una figura insular y excéntrica dentro de este período. La actitud inconformista y polémica adquiere en su narrativa ribetes más complejos; el canon realista aparece distorsionado por una alucinante imagen de la vida, intensificado hasta los límites de lo grotesco. Desde su primera novela, La mujer desnuda (1950), sobresale por la franqueza sexual y la perversa crueldad de una temática que intenta mostrar - con frecuencia en una prosa grandilocuente y sobrecargadaun mundo disonante y sin sentido.

Los narradores que se dan a conocer hacia 1960 se asimilan a las preferencias de sus mayores, prolongando el espíritu crítico del período: "generación de la crisis o de $1955^{\prime}$ la llama Rama, "generación de 1958” modifica Rodríguez Monegal, "generación de 1960" concluye, a su turno, Carlos Maggi, para registrar el momento en que un grupo de escritores se incorpora a la literatura nacional..$^{51}$ Sin embargo, no se trata de una nueva generación, marcada por el revisionismo de procedimientos estéticos o ideológicos, sino de un grupo de

${ }^{51}$ Rama, La generación critica, 173et seq.; Rodríguez Monegal, Literatura uruguaya del medio siglo, 406-407; Carlos Maggi, Sociedad y literatura en el presente, 39. 
escritores en distintas fases de desarrollo que forman una comunidad cultural. El entramado y la confluencia de diversos grupos demuestran la complejidad del procesoliterario, la riqueza de tonalidades contiguas y superpuestas en cualquier período histórico. La conciencia social, consecuencia del impacto de la revolución cubana y las expectativas del lector condicionan el agrupamiento natural de narradores que al iniciar su vida creadora no se apartan de las normas estéticas del período. Tal continuidad se percibe en los narradores que surgen en el primer lustro de los sesenta. Algunos de ellos se incorporan tardíamente al neorrealismo urbano (Juan José Lacoste, 1918; Ariel Méndez, 1920; Anderssen Banchero, 1925-1989; Jorge Musto, 1927; Mario César Fernández, 1928); otros están en el linde generacional (Sylvia Lago, 1932; Hiber Conteris, 1933); y un último grupo lo constituye los adelantados de una nueva generación (Claudio Trobo, 1936; Fernando Ainsa, 1937; Eduardo Galeano, 1940; y Cristina Peri Rossi, 1941). En su período formativo los más jóvenes gravitan hacia la generación anterior, formando constelación con ella, como es frecuente, en aparente unidad aunque en realidad pertenezcan a dos generaciones. ${ }^{52}$ Los primeros libros de los escritores mencionados se someten a la inmediatez cotidiana, sin modificar ni cuestionar los esquemas ficcionales heredados. En su comienzo no se apartan de códigos verosímiles, de tendencias denotativas de la realidad inmediata y de circunstancias históricas. Es una fase de transición - una época cumulativa, en la terminología de Ortega-en la que predomina la adhesión de jóvenes receptivos a la influencia de sus mayores, sin adquirir aquéllos en su etapa de gestación una fisonomía propia y diferencial. El proceso inevitable de decantación generacional hace que unos se pierdan y otros tiendan a distanciarse de su iniciación literaria.

Toda generación se escinde en tendencias divergentes y es natural que estéticas enfrentadas o contiguas coexistan dentro de un mismo periodo. "Esta superposición de estratos artísticos," observa Ángel Rama, le “confiere espesor a cualquier época histórica" ${ }^{53}$ Una de las vetas de mayor libertad imaginativa de la narrativa uruguaya, colindante con lo fantástico, la vertiente de Felisberto, se mantiene presente en los relatos de María Inés Silva Vila(1926), en Tratados y ejercicios (1967) de José Pedro Díaz y, ante todo, en la presencia tardía de Garini. Lugar aparte merece Maria de Montserrat (1915), por la mirada afectiva con que reconstruye el pasado, la vida de familias o barrios montevideanos, en una prosa estilizada. Un proceso paralelo es la sobrevivencia de la narrativa nativista como testimonio telúrico - Julio C. da Rosa (1920) es el ejemplo más destacable- y la renovación de los viejos motivos camperos por parte de Mario Arregui (1917-1985), cuya destreza expresiva trasciende el

\footnotetext{
52 Julián Marías, "Constelaciones y generaciones", Ensayos de convivencia (Buenos Aires: Sudamericana, 1966), 114-118.

${ }^{53}$ Rama, "Sistema literario y sistema social en Hispanoamérica", 98.
} 
regionalismo. A la convivencia sincrónica de tendencias radicalmente opuestas (social, fantástica, nativista) se suma un narrador rezagado que continúa en la actualidad la impronta neorrealista. Julio Ricci (1921), de creciente interés, recrea en El grongo (1976) y en libros posteriores las mediocres aspiraciones de la pequeña burguesía montevideana, dentro de un neorrealismo distorsionado por toques grotescos y de humor negro. A su vez, Antonio Larreta (1922), de larga trayectoria teatral, multiplica los peligros clasificatorios con Volavérunt (1980), novela humanística sobre la muerte de la Duquesa de Alba en 1802, fruto de su colaboración en una biografía de Goya para la televisión española.

La hegemonía aplastante de la estética neorrealista irá extinguiéndose a lo largo de los sesenta, al desaparecer las condiciones sociales que constituían su temática, el Uruguay pequeño-burgués, en vísperas de desmoronamiento. El agotamiento de un cicloliterario coincide, naturalmente, con la irrupción de una nueva generación.

\section{UNA NUEVA CONCIENCIA Y UN NUEVO LENGUAJE}

Las primeras publicaciones de los nuevos narradores fueron poco auspiciosas. A comienzos de los sesenta, cuando se inicia el auge editorial y el interés en el producto local, surge una narrativa que acentúa aspectos superficiales de la vida juvenil, sin la riqueza expresiva y la experimentación formal que impulsó a un fenómeno paralelo, la "onda" mexicana de Gustavo Sáinz, José Agustín y otros. Literatura de balneario, bautizó peyorativamente Benedetti a esta corriente, por la reiterada presencia de desencantados conversadores que se aburren confortablemente en balnearios de moda, por "la perspectiva de ver convertida nuestra literatura en un gigantesco y soleado médano" ${ }^{54} \mathrm{El}$ espíritu de esta narrativa asoma hasta en los propios títulos de algunas de las obras publicadas en la década: Tan solos en el balneario de Sylvia Lago, Los veranos y los inviernos de Lacoste, Un breve verano de Banchero, El nadador de Conteris, En la orilla de Ainsa, Crónicas de cuatro estaciones y Veraneo de Juan Carlos Legido, Confesiones de un adolescente y Calles que dan al mar de Alberto Paganini, Sin horizonte y Los amigos de Trobo; otras como Un largo silencio de Musto y Forma de piel de Juan Carlos Somma están situadas en balnearios, aunque esta última intenta ahondar en prejuicios de la comunidad católica. En todas ellas es evidente el arraigo del neorrealismo: el fraseo descriptivo, la enunciación directa y el lenguaje mimético con que testimonian el hastío y la alienación afectiva, sin proyectarse más allá de aspectos superficiales de la convivencia. Demasiado apegados a relaciones anímicas y a la presentación objetiva de los hechos, escriben historias amenas pero de una inmediatez fatigosa, en un tono monocorde que acentúa el estatismo de las escenas, la incomunicación y el desasosiego tributarios de Cesare Pavese, la cinematografía de Antonioni y la

${ }^{4}$ Benedetti, Literatura uruguaya siglo XX, $2^{\mathrm{a}}$ ed. (Montevideo: Alfa, 1969), 332. 
nouvelle vague francesa. Ya en 1963 Ángel Rama advirtió esta actitud derivativa y convencional, para añadir: "Es peligrosa la ausencia de afán experimentador entre los jóvenes, y conviene afirmar dogmáticamente que sin experimentación constante no hay arte original y verdaderamente nuevo" ${ }^{.5}$ Fue una narrativa sensible a lo banal, en la que nada "pasa fuera del alcohol, del vagabundeo automovilístico y sexual, al que se ciñen en forma casi unánime ${ }^{7 .}{ }^{56}$ Esta carencia es su mayor mérito: recrear el hedonismo y el cinismo de una burguesía ociosa, desentendida de la crisis que resquebrajaba al país.

Hacia mediados de los sesenta se advierten síntomas inequívocos de una modulación artística diferente, de una escritura inventiva. "Días dorados de la señora pieldediamante" (1965) y Detrás del rojo (1967) de Sylvia Lago, Zoologismos (1967) de Mercedes Rein, El otro equilibrista (1967) de Gley Eyherabide y Gelatina (1968) de Mario Levrero presagian la apertura hacia orientaciones más diversificadas y de mayor espontaneidad imaginativa. Por esos mismos años los jóvenes se manifiestan colectivamente en tres revistas generacionales de corta vida, que inician la ruptura definitiva con la generación anterior: Los huevos del Plata, Brecha y Prólogo . ${ }^{57}$

Paulatinamente los nuevos narradores comienzan a buscar vías de expresión más libres y experimentales, más conscientes de las posibilidades creativas del lenguaje. Los narradores que llegan a la madurez en los setenta se circunscriben a dos pautas fundamentales: por un lado, ya no son epigonos de los grandes narradores sociales de la generación de 1954, que responden a exigencias de la mímesis; por otro, se distinguen por la exploración inventiva, por una mayor libertad para abordar el hecho literario. Es ya incuestionable que 1969 debe ser considerado el año central de la nueva generación: Contramutis (1969) de Jorge Onetti, ${ }^{58}$ El libro de mis primos y Los museos abandonados (ambos de 1969) de Peri Rossi, La máquina de pensar en Gladys y La ciudad (ambos de 1970) de Levrero son obras decisivas que animan la tendencia irrealista que caracteriza a la generación..$^{59}$

La crisis política y económica se agrava hacia 1968, entrando el país en una etapa de conmoción social sin precedentes. El progresivo desmoronamiento de la infraestructura económica (la industria agropecuaria) y la pugna ideológica condujeron a la acción directa -laguerrilla urbana por parte de los tupamaros--

\footnotetext{
${ }^{56}$ Rama, "Los nuevos compañeros", Marcha, 1189 (27 diciembre 1963), 2.

${ }^{56}$ Fernando Ainsa, Tiempo reconquistado (Montevideo: Géminis, 1977), 67.

${ }^{67}$ Los huevos del Plata, 0-13, 1965-1969, Director: Clemente Padín; Brecha, 1-2, 1968 1969, director: Hugo Achugar; Prólogo, 1-3, 1968-1969, directores: Conteris, Eyherabide, Guiral, Musto, Rosencof, Ruffinelli, Saad, Somma.

${ }^{58}$ Jorge Onetti, argentino de nacimiento, hijo del autor de La vida breve, residía en Montevideo cuando publicó Cualquiercosario y Contramutis.

${ }^{59}$ Jorge Ruffinelli, "La década literaria", Enciclopedia uruguaya 57 (Montevideo: Arca, 1969), 127-131.
} 
y a la violencia institucional -la supresión de las libertades civiles y la represión militar. A partir de 1969 (la toma de la ciudad de Pando por los tupamaros, el 8 de octubre, es paradigmática), la crisis social desemboca en la barbarie cotidiana, sin parangón desde la guerra civil de 1904. Paulatinamente las alteraciones de la sociedad son más radicales: dictadura militar (19731985), empobrecimiento nacional, encarcelamientode escritores (Onetti, Quijano, Nelson Marra, Conteris, Mauricio Rosencof, etc.), o exilio masivo. Una de las repercusiones más perniciosas fue la aniquilación de la vida cultural del país: el cierre de publicaciones disidentes y la censura impidieron la difusión de ideas, la interrupción de la entrada de libros extranjeros y la destitución de los docentes de la enseñanza media y universitaria produjeron trastornos con vastas ramificaciones, sumiendo al país una vez más en el provincialismo y la marginalidad.

Las bases necesarias para el tránsito de un período literario a otro son ya evidentes: el agotamiento del canon realista correlacionado con un violento quiebre institucional en una sociedad en proceso de transformación. Cabe preguntarse hasta qué punto factores de indole social e ideológicos nunca antes enfrentados afectan la actividad creadora de los escritores de esta generación. Con anterioridad al golpe militar de 1973 había actividad política disidente; una de las propuestas fue darle a la literatura una finalidad panfletaria, al servicio de la revolución. Paganini exige en 1969 una literatura proletaria, "un arte para las masas, una producción en serie", y proclama, con demagogia: "La literatura que escriba nuestra generación será literatura revolucionaria o no será literatura" ${ }^{.0}$ La novela que Paganini publica ese mismo año, Calles que dan al mar, contradice su propia tesis: con fina elegancia cuenta historias sentimentales en Punta del Este, plácido refugio de la élite uruguaya, culminación estética justo es reconocerlo- de la literatura de balneario. Los escritores más representativos rechazan la toma de posición explícita frente al proceso social y político del país, acentuando la fabulación imaginativa. No cabe duda que la tónica general de la narrativa del período se aparta de los cánones de verosimilitud. Hay una gradual interiorización de lo cotidiano concreto y un repliegue hacia la subjetividad; el lenguaje pierde su transparencia, deja de ser instrumento de comunicación directa, la prosa se hace multialusiva y formas fantásticas, alegóricas, lúdicas o líricas subvierten los modelos establecidos por lageneración anterior. En 1972, Rama resume con lucidez los rasgos distintivos de la nueva narrativa:

una desconfianza generalizada por las formas recibidas que traducen el mundo real, a partir de la comprobación de que las bases de ese mundo se presentan como repentinamente inseguras, inestables, imprevisibles, adquiriendo un

${ }^{60}$ Alberto Paganini, "Tesis polémica sobre la generación del 60", Prólogo, 2-3 (1969): 13 y 11 , respectivamente. 
estado fluido propio de inminentes cambios, rehusándose a cristalizaciones en estructuras firmes, rehusando todo punto de apoyo s6lido y preciso. Tal vivencia explica la nota experimental que domina la búsqueda de correlatos estéticos de lo real en esta literatura, poblando los textos de visiones estremecedoras del medio ambiente; [...] una irrupción sobre ese magma inseguro, que remeda lo real, de un despliegue imaginativo signado por una nota de libertad irrestricta que fácilmente se confunde con la gratuidad, con el juego, con la alucinación onírica, quizás porque se desplaza en el exclusivo campo de la imaginación funcionando en una zona sin resistencias, como si hubiera cortado o suspendido temporariamente sus lazos con aquella realidad, que, al devenir cambiante, insegura, impredecible, ha dejado de condicionar o limitar el funcionamiento de la imaginación que normalmente desde ella parte y a ella responde u obedece $\ldots . . .61$

El libre juego de la imaginación se manifiesta desde la fase de formación de estos escritores - que es la decisiva-y llega a su madurez en 1969, época de inseguridad social pero de plena libertad expresiva. Es falso, por lo tanto, explicar el predominio de la narrativa imaginativa en el Uruguay actual como resultado de la represión dictatorial. Con posterioridad al golpe de estado de 1973 la censura y la autocensura impiden la crítica explícita de la situación social y se recurre con mayor frecuencia a formas del decir elusivo, a la distorsión de contextos sociales y a la alegoría como vehículo expresivo. A lo largo de los setenta se acumulan escritores que incursionan en zonas inseguras o indeterminadas de la realidad, acentuándose hacia 1980 la fabulación lúdica, fantástica o mítica, dentro y fuera de fronteras. ${ }^{62}$ Algunos ejemplos destacados: Construcciones (1979) de Teresa Porzecanski, París (1979) y El lugar (1982) de Levrero, La rebelión de los niños (1980) y cinco libros más recientes de Peri Rossi, Lucifer ha llorado (1980) de Enrique Estrázulas, Donde llegue el Río

${ }^{61}$ Rama, La generación crílica, 238-239.

62 Sobre la nueva narrativa, véanse: Armonía Somers, "Diez relatos a la luz de sus probables vivencias", postfacio a Diez relatos y un eptlogo (Montevideo: Fundación de Cultura Universitaria, 1979), 113-154; Graciela Mántaras Loedel, "El manierismo en la nueva narrativa uruguaya", Brecha (9 mayo 1986): 30-31; Teresa Porzecanski, "Ficción y fricción de la narrativa de imaginación escrita dentro de fronteras", Represion, exilio y democracia: la cultura uruguaya, ed. Saúl Sosnowski (Montevideo: Banda Oriental, 1987), 221-230; Hiber Conteris, "Tras la pista de la nueva narrativa uruguaya", Asamblea (Montevideo), 6 noviembre de 1985, 23. Con posterioridad a la redacción de este artículo aparecieron varius trabajos importantes, entre ellos: Mabel Moraña, Memorias de lageneración fantasma (Montevideo: Monte Sexto, 1988); Rómulo Cosse, Fisión literaria: narrativa y proceso social (Montevideo: Monte Sexto, 1988); Jorge Ruffinelli, "Uruguay: dictadura y re-democratización", Nuevo Texto Critico 5 (1990): 37-66; y María Rosa Olivera-Williams, “La literatura urugu aya del Proceso”, Nuevo Texto Crttico. 5 (1990), 67 83. 
Pardo (1980) de Miguel Ángel Campodónico, La noche del día menos pensado (1981) de Héctor Galmés y Casa vacía (1983) de Mercedes Rein. ${ }^{63}$

Todos ellos certifican la vitalidad y la diversidad de la narrativa uruguaya reciente. Dentro de este marcogeneracional predominante -l sesgo imaginativo como subversión de los hábitos de lectura y de la percepción de la realidadsobresalen, a mi juicio, Mario Levrero (1940), injustamente relegado por la crítica, y Peri Rossi (1941). La frase de Kafka que Levrero usa de epígrafe en La ciudad, "veo algo [...] nada más que algunos contornos imprecisos de la niebla", sintetiza la atmósfera onírica y fantasmagórica de sus tres primeras novelas (las otras son El lugar y París), relatos que plantean situaciones azarosas que mantienen desconcertado al lector. Seres desubicados, en incesante búsqueda de un "lugar" o refugio y en perpetua huida a/de lo desconocido, devienen imagen del extrañamiento y de la acción enajenante de la sociedad contemporánea. Peri Rossi es también escritora de imaginación desbordante, de obra multifacética. La disolución de toda categoría realista se agudiza en su narrativa; la difuminación de los márgenes genéricos, el despliegue de una fantasía desmitificadora, la sátira, la alegoría, el erotismo, la actitud lúdica y la continua experimentación verbal son rasgos distintivos de su obra. La irónica reflexión sobre el naufragio colectivo de la sociedad moderna llega a sus extremas posibilidades en La nave de los locos (1984) y en Una pasión prohibida (1986); ambos libros confirman el lugar de privilegio de Peri Rossi en la narrativa continental.

Eduardo Galeano (1940) es un escritor versátil, autor de una extensa obra periodística que incluye un libro excepcional, Las venas abiertas de América Latina (1971). Su temprana inserción en el mundo intelectual -escribe desde los quince años - condicionado por la vigencia de la generación neorrealista, explica que su "edad social" sea mayor que la efectiva. ${ }^{64}$ Sus primeros dos libros de narrativa fueron, irremediablemente, complementarios. Su obra de madurez, escrita en el exilio argentino -Vagamundo (1973) y La canción de nosotros (1975) - manifiesta claramente las normas y pautas de su generación: la conciencia del lenguaje y la libertad imaginativa. Recurre al mito, a la leyenda, a la historia y a la poesia, enlaza la miseria cotidiana con los sueños de crear un espacio polifónico, en el que entreteje dispares voces latinoamericanas que abarcan desde el candor inocente a la lucha revolucionaria. A partir de 1976, en un nuevo exilio, en Barcelona, la narrativa de Galeano se vuelve testimonial. En Días y noches de amor y de guerra (1978), conjunción de periodismo, ensayo político y narración, entrecruza el diario personal y la denuncia de las dictaduras

\footnotetext{
${ }^{63}$ Naturalmente siempre hay excepciones. Otros narradores hábiles de la actualidad se inscriben en tendencias más apegadas a la realidad inmediata, a sicologías y ambientes pueblerinos. Por ejemplo, Rubén Loza Aguerrebere (1943), Milton Fornaro (1947), Tomás de Mattos (1947) y Mario Delgado Aparaín (1949).

64 Julián Marias, El método histórico de las generaciones, 167.
} 
militares latinoamericanas. Yen la trilogíaMemoria del fuego (1982-1986) borra aún más los límites genéricos; sobre base documental rehace la historia de América Latina, desde la época precolombina a nuestros días, como sucesión de mitos, leyendas y viñetas, elaborando un relato a mitad de camino entre la crónica y la ficción.

La tendencia testimonial, motivada por fuerzas ideológicas, no queda circunscrita a una generación. En el exilio, Musto, Martínez Morenoy Benedetti escriben novelas de evidente carácter catártico (El pasajero, 1977, El color que el infierno me escondiera, 1981, y Primavera con una esquina rota, 1982, respectivamente), que testimonian una realidad política, la lucha guerrillera. Saúl Ibargoyen recupera la tradición oral popular de un pueblo fronterizo bajo la represión (La sangre interminable, 1982), escrita en un lenguaje híbrido. La reconstrucción democrática del país cambia las condiciones de producción y de recepción de la literatura dentro de fronteras: un público ávido de información, tras doce años de silencio, reclama saber los horrores vividos y se publican crónicas testimoniales sobre la dictadura, la cárcel, la represión, la marginalidad o el exilio, que documentan fenómenos sociales no registrados con anterioridad. Las manos en el fuego (1985) de Ernesto González Bermejo y Memorias del calabozo (1988) de Mauricio Rosencof y Eleuterio Fernández Huidobro fueron objeto de gran acogida popular.

La represión dictatorial afectó de modo radical la vida de los novísimos narradores, nacidos aproximadamente de 1947 en adelante. El contacto vital entre ellos resultó impedido por la cárcel y el exilio, su desarrollo cultural alterado por la desinformación, la censura y la crisis económica que desmanteló instituciones, editoriales y órganos de expresión. Es prematuro vaticinar sobre el destino literario de jóvenes cuyos alcances están aún por determinarse. Bien puede ser una generación nominal, aunque hay ya muestras de continuidad, sin modificaciones profundas con el repertorio de formas y de pautas en vigencia, la narrativa imaginativa y lúdica: dentro de fronteras, Aperturas miniaturas finales de Juan Carlos Mondragón (1951) y Posibles versiones (1985) de Elbio Rodríguez Barilari (1953); en el extranjero, La manipulación (1987) y El turismo infame (1987), novelas de Roberto Fernández Sastre (1951). El renacimiento editorial y el aumento considerable de publicaciones nacionales es un signo altamente positivo. aunque la eventual superación de la crisis generalizada constituye un hecho todavía imprevisible.

\section{POSTDATA DE NOVIEMBRE DE 1991}

A más de tres años de escrito este trabajo, sería necesario reconsiderar algunos presupuestos y recoger nuevas modalidades narrativas. Me limito a destacar el auge local de la revisión crítico-imaginativa de la historia, en consonancia con la actualidad del subgénero en América Latina o, más específicamente, el interés en la "metaficción historiográfica", en la narrativa 
que agrega al referente histórico un sentido irónico de distancia crítica. ${ }^{65}$ Mediante la parodia la nueva novela histórica problematiza y subvierte los propósitos de veracidad y las perspectivas autoritarias que mueven a la modalidad tradicional. Amodo de ejemplo, menciono tres novelas estrechamente vinculadas a los orígenes de la nacionalidad o a los mitos fundacionales de Hispanoamérica: Morir con Aparicio (1985), de Hugo Giovanetti Viola (1948), ¡Bernabé, Bernabé! (1988), de Tomás de Mattos (1947), elaboradas ambas en torno de figuras protagónicas de la gesta nacional y, principalmente, Maluco (1990), de Napoleón Baccino Ponce de León (1947), novela que reconstruye el viaje de Magallanes, contado por el bufón de la flota. La reescritura paródica e irreverente de Baccino desmitifica la historia oficial, volviéndose ésta más elusiva y polivalente. En los umbrales del Quinto Centenario, Maluco se contrapone de forma expresa al absolutismo eurocéntrico y opera dentro de un necesario revisionismo de la identidad cultural hispanoamericana.

${ }^{65}$ Sobre la metaficción historiográfica, véase Linda Hutcheon, A Poetics of Postmodernism (New York: Routledge, 1988). 
